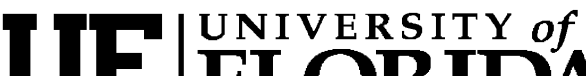 FLORIDA \\ IFAS Extension
}

\section{Insect Management in Your Florida Lawn ${ }^{1}$}

\section{Eileen A. Buss and J. Bryan Unruh²}

Several insects and insect relatives live in Florida lawns, but not all of them hurt the grass. Many are harmless, some are beneficial, and some are pests. Only a few cause significant damage and need immediate control. For example, chinch bugs, spittlebugs, and grass scales live on the plant foliage and suck plant juices. Other pests, including sod webworms, grass loopers, and armyworms, eat the grass leaves. Mole crickets, white grubs, and billbugs live in the soil and primarily damage grass roots, in addition to creating tunnels and/or mounds. Other insects and related pests (e.g., fleas, millipedes, chiggers, sowbugs, and snails) are nuisances because they may bite people or pets or invade houses, garages, or swimming pools.

Sometimes its easy to confuse beneficial insects for pests. For example, certain insects (e.g., big-eyed bugs, anthocorids, and nabids) look like chinch bugs, but are actually predators and feed on chinch bug eggs and nymphs. Earwigs, ground beetles, and spiders search through the grass and feed on chinch bugs, webworms, and several other lawn pests. The presence of beneficial organisms likely prevents the insect pests from increasing to damaging levels. However, such natural enemies can't kill all of the pests. A small pest population needs to survive to maintain these beneficial organisms. Preventive or by-the-calendar treatments (pesticide applications made every 4 to 8 weeks) may kill many beneficial organisms and contribute to a persistent pest problem. Thus, pesticides should be applied only when damage is apparent.

Research has demonstrated that the need for pesticide applications to control insect outbreaks can be drastically reduced by following these management practices.

\section{Monitoring}

Early detection of insects is vital to any management program. Check the lawn for pest activity every 14 days in the winter and every 7 to 10 days in the spring, summer, and fall, especially in "hot spots" where damage tends to reoccur.

Factors other than insect outbreaks may also result in thin or brown grass, including diseases,

1. This document is Circular 427 (LH034), Florida Cooperative Extension Service, Institute of Food and Agricultural Sciences, University of Florida. This information is included in the Florida Lawn Handbook, SP-45. For a copy of this handbook, request information on its purchase at your county extension office. First published: June 1990. Revised: August 2006.

2. Eileen A. Buss, assistant professor,Entomology and Nematology Department, Cooperative Extension Service, Institute of Food and Agricultural Sciences, University of Florida, Gainesville, 32611 and J. Bryan Unruh, associate professor, Environmental Horticulture Department, West Florida REC, Milton, 32583.

The use of trade names in this publication is solely for the purpose of providing specific information. UF/IFAS does not guarantee or warranty the products named, and references to them in this publication does not signify our approval to the exclusion of other products of suitable composition. Use pesticides safely. Read and follow directions on the manufacturer's label.

The Institute of Food and Agricultural Sciences (IFAS) is an Equal Opportunity Institution authorized to provide research, educational information and other services only to individuals and institutions that function with non-discrimination with respect to race, creed, color, religion, age, disability, sex, sexual orientation, marital status, national origin, political opinions or affiliations. U.S. Department of Agriculture, Cooperative Extension Service, University of Florida, IFAS, Florida A. \& M. University Cooperative Extension Program, and Boards of County Commissioners Cooperating. Larry Arrington, Dean 
nematodes, drought, and nutritional disorders. Correct identification of the problem can save money, prevent excessive damage to the grass and unnecessary pesticide applications.

\section{Cultural Practices}

How the grass is grown and maintained often affects insect survival and development. In general, healthy turf is less vulnerable to pests and can recover faster from an infestation.

\section{Nutrition}

Over-fertilization generally increases plant susceptibility to sap-feeding insects. Some insects tend to feed more on actively-growing plant parts, rather than the older, slower-growing ones. Incidence of damage from these pests can be greatly reduced with applications of minimum amounts of slow-release nitrogen fertilizers in combination with other macro-and micronutrients. Contact your local county Cooperative Extension office for fertility recommendations and sources of slow-release nitrogen fertilizer for each of the turfgrass species in your particular area of the state.

\section{Mowing}

Improper mowing, coupled with over-watering and improper fertilization can cause lawn grasses to develop a thick, spongy mat of live, dead, and dying shoots, stems and roots which accumulate in a layer above the soil surface. This spongy mat, called thatch, is an excellent habitat for chinch bugs and turf caterpillars, and chemically ties up insecticides, therefore reducing their effectiveness. When a serious thatch problem exists, it may be necessary to remove the thatch mechanically (vertical mowing, power raking, etc.). Proper mowing practices can make grass more tolerant to pests and greatly improve the appearance of a lawn. The best recommendation is to mow often enough so that no more than one-third of the leaf blade is removed at each mowing.

\section{Insects in your Florida Lawn}

Because of Florida's varied climatic and environmental conditions, many different insects can become problematic in your Florida lawn. The following sections describe a number of these destructive pests.

\section{Billbugs}

\section{Description}

An adult billbug is a black beetle (weevil) that has a "bill" or snout (Figure 1). The chewing mouthparts are at the end of the snout. Hunting billbug adults have a raised Y-shaped area surrounded by curved lines on the prothorax (behind the head) and rows of large and small pits on the wing covers (elytra). Billbug larvae are white, legless grubs with brown heads.

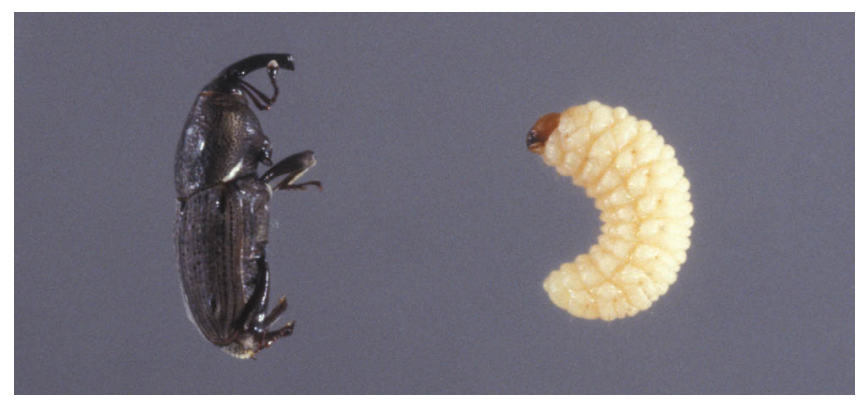

Figure 1. Hunting billbug adult (left) and larva (right). Credits: L. J. Buss, University of Florida

\section{Life Cycle}

Hunting billbugs appear to have 1-2 generations each year, but all life stages may be present at a time. Eggs are laid in the leaf sheaths or top of the crown and hatch within about 10 days. Young larvae feed on the inner leaves and chew down to the roots. Pupation occurs in the soil or roots and may last up to 7 days.

\section{Monitoring}

Billbugs are found throughout Florida and have become more of a problem in recent years. If grass consistently wilts in an area of the turf despite proper irrigation, an infestation of root-feeding billbugs should be considered. Monitor off-color areas by cutting 1 square foot of sod, 2 inches deep. Lay back the sod, examine roots for chewing damage, and check the soil and thatch for larvae. Replace the strip of sod and irrigate it. Check several places. 


\section{Damage}

Zoysiagrass and bermudagrass are preferred hosts for the hunting billbug. Most damage occurs in the fall and spring when populations are high, and may be misdiagnosed as dormancy. Dead patches or areas that green up slowly may also be noticed in the spring. Stems and rhizomes break easily, have irregular feeding marks, and turf will not hold together if cut. Most damage occurs on infertile or dry soil. Adults also make small mounds when exiting the soil.

\section{Control}

Treatment may be necessary if 10 to 12 billbugs are found per square foot. The soil should be moist at the time of insecticide application. Immediately irrigate with about $1 / 2$ inch of water after applying the insecticide, to move it into the soil where the insects are feeding. Parasitic nematodes (Steinernema and Heterorhabditis) and Beauveria fungi can also effectively control billbug larvae and adults.

\section{Fall Armyworms, Cutworms, and Grass Loopers}

\section{Description}

Fall armyworms (Figure 2), cutworms (Figure 3 ), and grass loopers (Figure 4) are brown to greenish in color and have stripes along their sides. Adults of the fall armyworm are light brown moths with a wingspan of about 1 1/2 inches. A fall armyworm caterpillar is greenish when small and dark brown when mature. It has a light midstripe on its back with darker bands on either side. The midstripe ends in an inverted "Y" on the head. Cutworm caterpillars are mostly hairless. Fall armyworms, cutworms and grass loopers grow to about 1 1/2 inches in length.

\section{Life Cycle}

Fall armyworms and grass oopers may be present during the spring, summer or fall. Moths lay eggs on grass or almost any object near lawns, which hatch within 2 weeks.

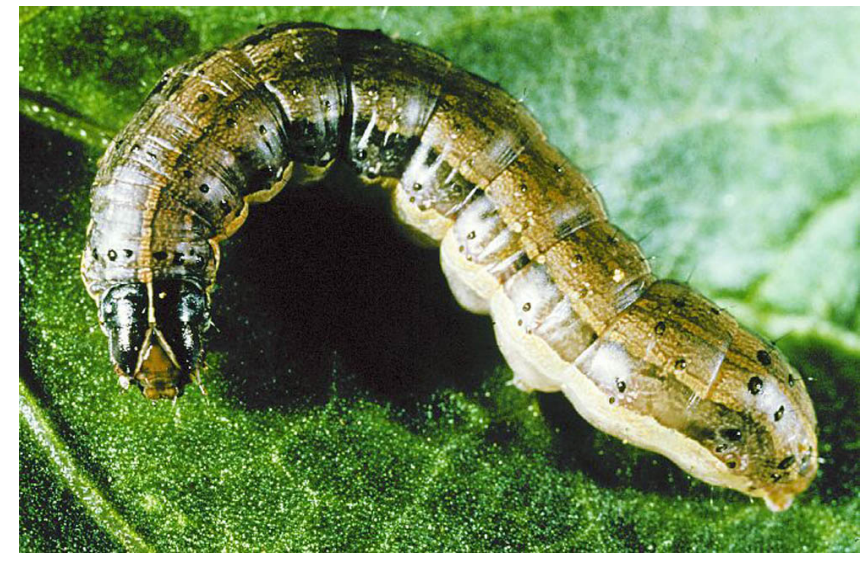

Figure 2. Fall armyworm. Credits: L. J. Buss, University of Florida

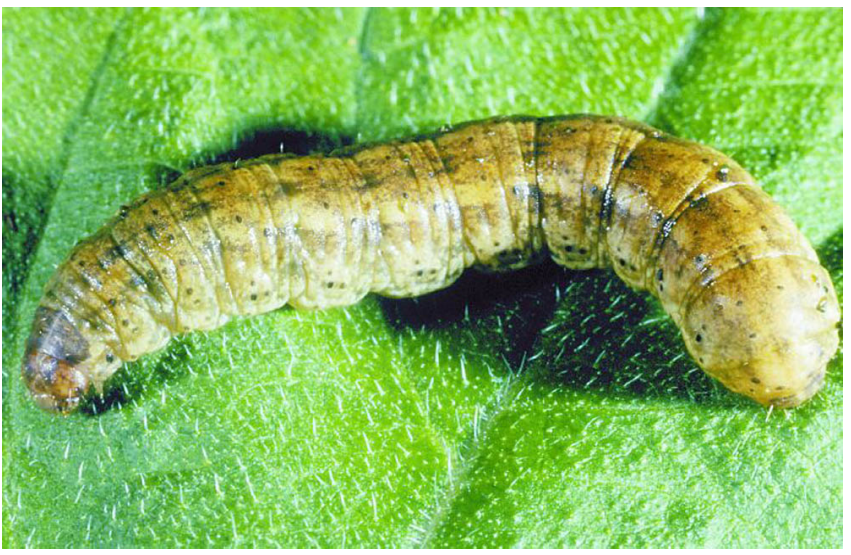

Figure 3. Granulate cutworm. Credits: J. L. Capinera, University of Florida

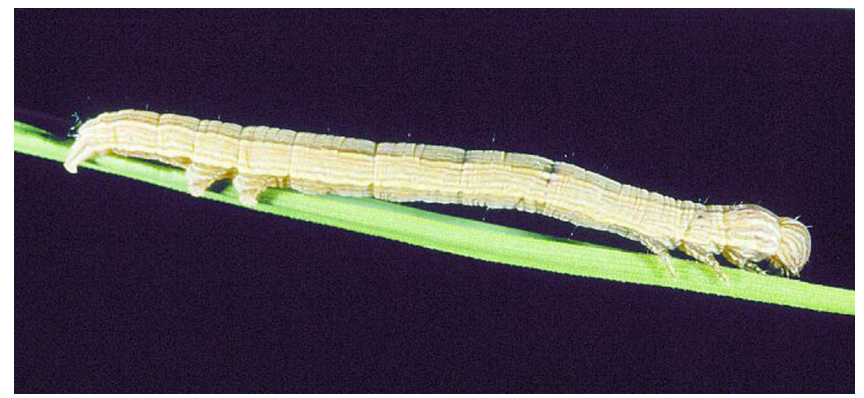

Figure 4. Grass looper. Credits: J. L. Capinera, University of Florida

\section{Monitoring}

Monitor by mixing 1 TBSP of liquid dishwashing soap in 1 gallon of water; pour the solution onto 4 square feet near the damage. Insects will crawl to the surface if present. Examine several suspected areas. Adults fly to lights at night. 


\section{Damage}

Fall armyworm damage is often scattered and not confined to patches. Populations of fall armyworms and other lawn caterpillars often feed at the same time in the same location. Fall armyworms and loopers feed during the day and do not rest in a curled position. Cutworm caterpillars usually dig a burrow in the ground or thatch (or use an aeration hole) and emerge at night to chew off grass blades and shoots. This damage may appear as circular spots of dead grass or depressed spots that look like ball marks on golf greens.

\section{Ground Pearls}

\section{Description}

Ground pearls (Figure 5) are scale insects that live in the soil and suck the fluids from the roots of most turfgrasses, but prefer centipedegrass. They occur throughout Florida, but are more abundant in northern and north-central Florida.

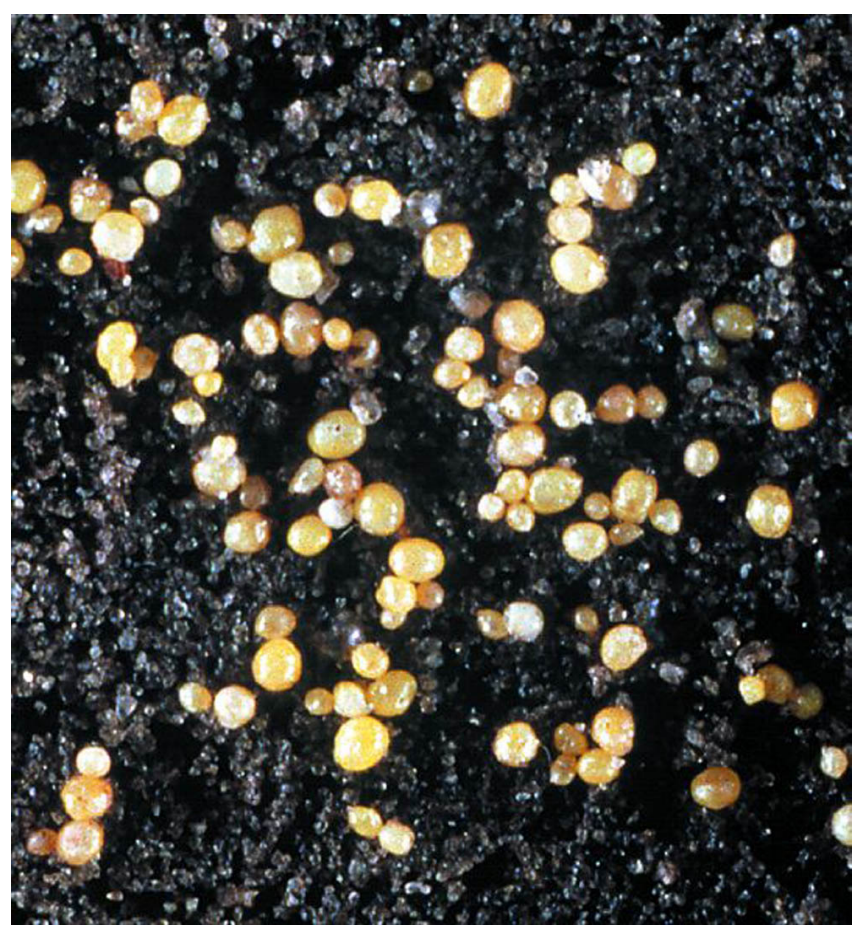

Figure 5. Ground pearls. Credits: J. L. Castner, University of Florida

\section{Life Cycle}

Clusters of pinkish-white eggs, covered in a white waxy sac, are laid in the soil from March to June. Tiny crawlers hatch from eggs, find a root, insert their piecing-sucking mouthparts, and cover themselves with a hard, yellowish to purple, globular shell. These round "pearls" range in size from a grain of sand to about $1 / 16$ inch in diameter. They may occur as deep as 10 inches in the soil. After emerging from the "pearl", the adult female is $1 / 16$ inch long, pink-colored, with well developed forelegs and claws. Adult males are rare, tiny, gnat-like insects. One generation may last from 1 to 2 years, or longer.

\section{Damage}

Symptoms attributed to ground pearl injury are first a yellowing and then browning of the grass. Stressed grass is most susceptible to injury, and may not be able to outgrow or survive ground pearl feeding damage. Properly watered and well-managed lawns often lack symptoms despite being heavily infested. Other factors such as disease, nutritional inbalances, drought or nematodes (especially in centipedegrass) may cause off-color areas in lawns. The lawn should be carefully examined to determine which corrective measures may be needed. Weeds also tend to invade areas infested with ground pearls.

\section{Control}

Minimize plant stress and maintain proper fertility and soil moisture to help grass tolerate the damage. No insecticides are currently available for ground pearl control.

\section{Mole Crickets}

\section{Description}

Three non-native species of mole crickets occur in Florida, including the tawny (Figure 6), southern, and shortwinged mole crickets. Adults are about 1 1/2 inch long, light brown, and have enlarged forelegs that they use to dig in soil. The forelegs have large blade-like projections, called dactyls, and the number and arrangement of dactyls, as well as the pronotum pattern (area behind the head), are used to identify different species (Figure 7). Nymphs look like adults, but their wings (wing pads) are not completely developed and they can't reproduce. Shortwinged mole cricket adults have short wings and cannot fly. 


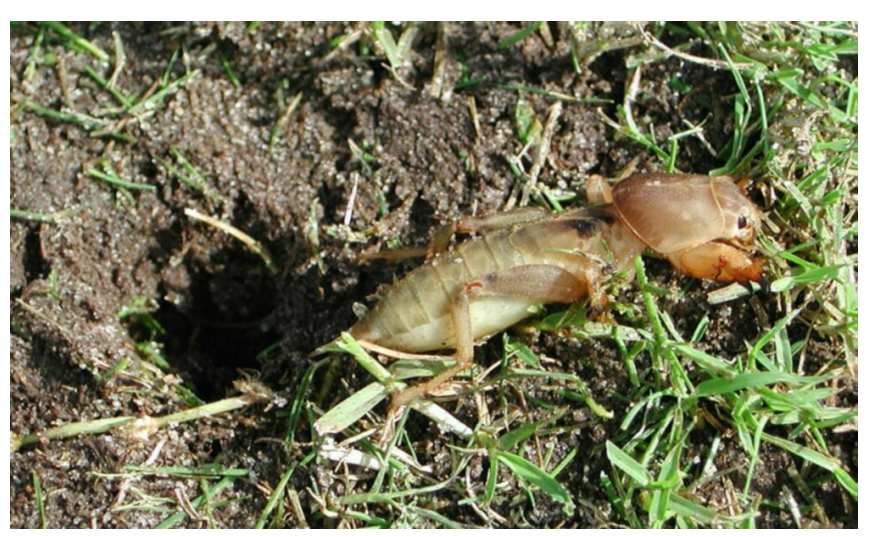

Figure 6. Tawny mole cricket. Credits: E. A. Buss, University of Florida

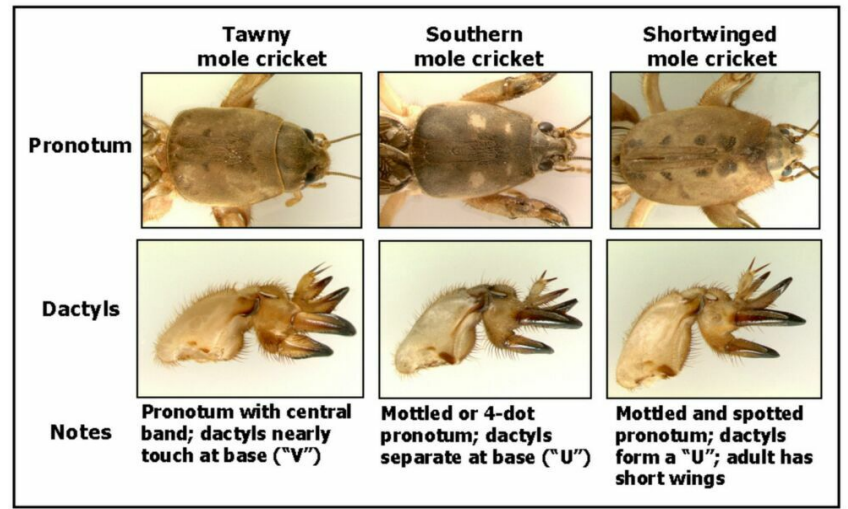

Figure 7. Key traits used to identify Scapteriscus spp. mole crickets. Credits: L. J. Buss, University of Florida

\section{Life Cycle}

In northern and central Florida, egg laying by tawny and southern mole crickets usually begins in March and peaks in May through mid-June. Due to warmer temperatures, adult southern and tawny mole crickets emerge 1 to 2 weeks earlier in southern Florida. However, the shortwinged mole cricket can produce eggs throughout the year in southern Florida. Mole crickets lay their eggs in chambers between 2 to 12 inches below the soil surface. In moist soil, egg chambers are closer to the surface, and are deeper in dry conditions. Females may lay up to 4 or 5 clutches of eggs containing about 25-60 eggs per clutch. Eggs develop in about 3 weeks, and most hatch during early June in northern Florida and through August in southern Florida. Some adults occur in the fall, but both nymphs and adults overwinter. Overwintering nymphs become adults in the spring, and adults fly and mate. One generation per year is normal, though the southern mole crickets have two generations and fly three times (spring, summer, and autumn) in southern Florida.

\section{Monitoring}

Several methods are used to estimate mole cricket populations and assist in timing pesticide applications, if needed. First, look at the soil and count the number of tunnels that are visible.

Tunneling is easier to see in low-cut grass, and may be hard to see in St. Augustinegrass. Tunnels are most visible in early morning, when the dew is on the grass and the soil is moist. To actually find the mole crickets, use the soap flush as described in the Fall Armyworm section. Check several places in the lawn; if there are more than 2 to 4 mole crickets per square foot, control should be considered. In addition, watch for adult tawny and southern mole crickets near lights during their spring and fall dispersal flights (ca. 7-10 pm, Eastern standard time).

\section{Damage}

Mole crickets damage turfgrass in several ways. Nymphs and adults feed on grass roots and blades at night after rain or irrigation, during warm weather. Their tunneling near the soil surface dislodges plants or causes them to dry out. Small mounds of soil are also pushed up by late summer. More than 20 feet of tunneling per night can occur. Tunneling and root-feeding reduce turfgrass density and create patches of bare soil.

\section{Control}

\section{Beneficial Insects}

When mole crickets come to the soil surface, they are subject to predators including ants, ground beetles, earwigs, and spiders. Larger animals including raccoons, skunks, red foxes, armadillos, birds, and several toads also feed on mole crickets, but often damage turf areas when searching for them. Natural enemies, such as a parasitic wasp (Larra bicolor), the red-eyed fly (Ormia depleta), and a beneficial nematode (Steinernema scapterisci) have been released by University of Florida researchers to further suppress mole cricket numbers.

\section{Control with Pesticides}

If damage occurred the previous year or if excessive tunneling was noticed in the spring, a pesticide application may be needed. The best time to 
control mole crickets is in June in northern and central Florida, and in May in southern Florida. However, the nymphs will be small at this time, and damage may not be very noticeable. Using a soap flush, determine if mole crickets are present and treat accordingly.

Mole crickets can be controlled by sprays, granules, or baits. Use an insecticide specifically labeled for mole cricket control in home lawns. For best results, make sure the soil is moist (not soaked) when the treatment is applied. This helps the insecticide to penetrate into the soil, or in the case of baits, encourages mole crickets to come to the surface to feed on the bait. Immediately after applying a contact insecticide, apply $1 / 2$ inch of water to move the chemical into the top 1 to 2 inches of the soil. Bait formulations are useful against larger nymphs in late summer. Because mole crickets feed at night, baits should be applied in late afternoon or early evening. It is very important to scatter the bait evenly over the soil surface. Do not irrigate after application or apply a bait if rain is expected.

\section{Red Imported Fire Ants}

\section{Description}

Imported fire ants are aggressive, reddish brown to black ants that are $1 / 8$ to $1 / 4$ in long (Figure 8). They make dome-shaped nests out of soil (Figure 9), sometimes as large as 3 feet across and $11 / 2$ feet in height. Fire ants usually build mounds in sunny, open areas such as lawns, pastures, and meadows, but they may also be located in rotting logs, around trees and stumps, under pavement and buildings, and occasionally indoors.

\section{Life Cycle}

Red imported fire ants live in colonies that contain cream-colored to white immature ants ("brood"). The brood is comprised of the eggs, larvae, and pupae. Also within the colonies are adult ants of different types, or castes, which include winged males, winged females (which are unmated queens), workers of varying size, and one or more mated queens. The winged males and females fly from nests, usually in the spring and early summer, to mate in flight. Winged males and females do not

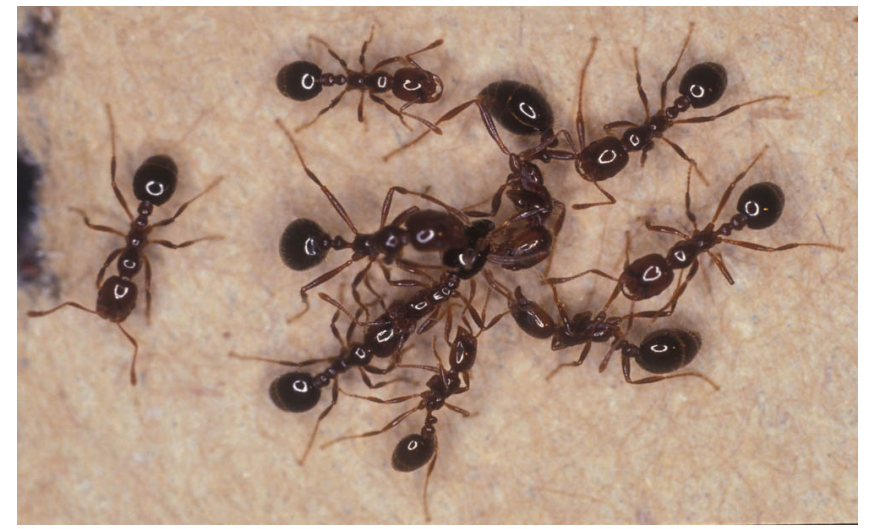

Figure 8. Red imported fire ant. Credits: J. L. Castner, University of Florida

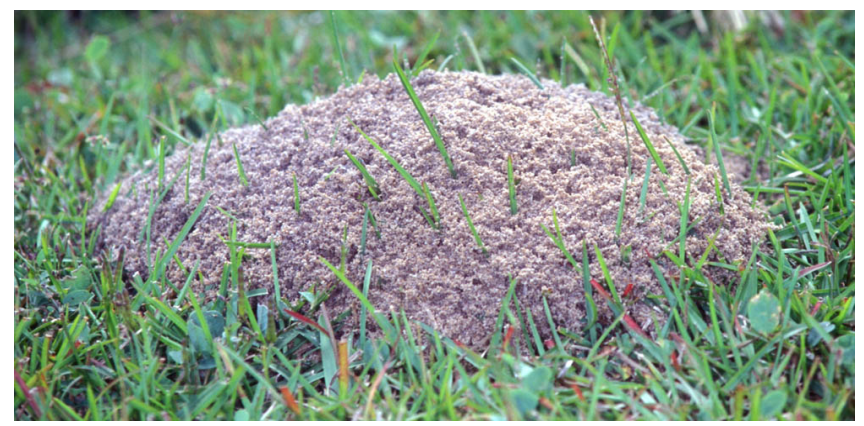

Figure 9. Red imported fire ant mound. Credits: L. J. Buss, University of Florida

sting, and less than $10 \%$ of the females survive to produce a colony. New colonies do not make conspicuous mounds for several months.

Fire ants feed on carbohydrates (e.g., honeydew, plant exudates, sugars, syrups), proteins (e.g., insects, meats), and lipids (e.g., grease, lard, oils from seeds). Their food preferences change depending on the nutritional requirements of the colony. Fire ants are only able to ingest liquids. Workers can forage for food more than 100 feet from the nest, day or night.

There are two types of fire ant colonies: single-queen (monogyne) and multiple-queen (polygyne) colonies. Single-queen colonies have only one egg-laying queen, and may contain as many as 100,000 to 240,000 workers. Multiple-queen colonies have many egg-laying queens (usually 20 to 60 ), with 100,000 to 500,000 workers. Single-queen colonies fight with other fire ant colonies. Because of this antagonistic behavior, colonies are farther apart, resulting in a maximum of 40 to 150 mounds per acre. Multiple-queen colonies generally do not fight with other multiple-queen colonies. Consequently, mounds are closer together, and can reach densities 
of 200 to 800 mounds per acre. Multiple-queen mounds may also be inconspicuous, often times being clusters of small, flattened excavations, in contrast to the distinct dome-shaped mounds of single-queen colonies. Workers from single-queen colonies vary in size, ranging in length from $1 / 8$ to $1 / 4$ in, and are usually reddish brown to black in color. Workers of multiple-queen colonies are generally smaller (1/8 to $3 / 16$ in), have only a few large workers, and are lighter in color (orangish-brown) than single-queen colony workers.

The large colony sizes, and the presence of numerous queens makes multiple-queen colonies more difficult to eliminate than single-queen colonies. Multiple-queen colonies produce fewer winged, or alate, queens that will start new colonies after a mating flight than single-queen colonies. However, multiple-queen colonies can establish new colonies by budding, where a portion of the queens and workers splits off from a colony.

\section{Damage}

When their nests are disturbed, numerous fire ants will quickly run out of the mound and attack any intruder (humans, pets, livestock, and wildlife). These ants are notorious for their painful, burning sting that results in a pustule and intense itching, which may persist for 10 days. Infections may occur if pustules are broken. Some people have allergic reactions to fire ant stings that range from rashes and swelling to paralysis, or anaphylactic shock, and death. Electrical equipment and utility housings may serve as fire ant nest sites, sometimes resulting in short circuits.

\section{Control}

Fire ants may be controlled using broadcast applications or by individual mound treatments. The types of products available for control generally include baits and contact insecticides. Most baits contain toxicants that are dissolved in an oil and impregnated into a small granule. The ant may either carry the granule back to the colony and extract the toxic oil within the mound, or extract the toxic oil from the grit immediately and carry it back to the colony internally and then spread it within the colony. Contact insecticides provide fast control, usually of workers. Keep in mind that to eliminate a fire ant colony, the queen must be killed or she will keep laying eggs and the colony will recover. Non-chemical control methods include applying hot water, and physically excavating the nest. All individual mound treatments may cause the ants to relocate and create a new mound. Even if the queen is killed, surviving ants may still inhabit the treated mound or make a new mound until they die off naturally, which may take over a month. Thus it may be necessary to retreat remaining mounds that still contain ants.

\section{Southern Chinch Bugs}

\section{Description}

The southern chinch bug (Figure 10) is the most important insect pest of St. Augustinegrass in Florida, but may also feed on other turfgrasses and weeds. Adults are about 3/16 inch long and are black with white patches on the wings. The young (nymphs) range from 1/16 inch long to nearly adult size. Small nymphs are reddish-orange with a white band across the back, but older nymphs and adults have black bodies.

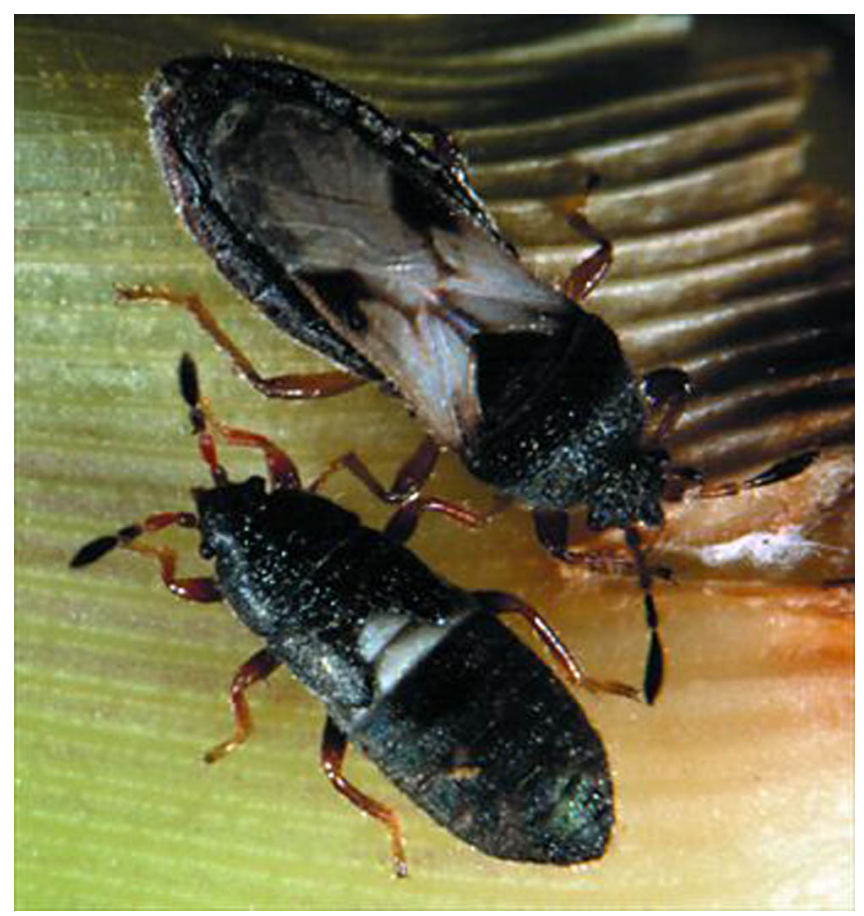

Figure 10. Southern chinch bug adult and nymph. Credits: J. L. Castner, University of Florida 


\section{Life Cycle}

All life stages are present year-round in most of the state. Eggs are laid in grass sheaths or pushed into soft soil and protected places. In summer, eggs hatch in 10 days and nymphs become adults in 4 weeks. There are 3 to 4 generations per year in northern Florida and 7 to 10 in southern Florida.

\section{Monitoring}

Chinch bugs can be found by several methods. First, part the grass and thatch near yellowed areas and look at the soil surface and base of the turf. Pull individual plants out and peel back the bottom leaves to look for feeding insects. Examine several different areas if chinch bugs aren't immediately found. In heavy infestations, chinch bugs can be seen crawling over grass blades and sidewalks.

Another option is to vacuum near a damaged area for about 2 minutes using a Dust Buster or hand-held vacuum cleaner. Remove the filter, dump the contents on the sidewalk, and look for nymphs and adults. Repeat in several damaged areas.

Final option is the flotation method. Cut both ends out of a metal can, such as a $3 \mathrm{lb}$ coffee can. Push or twist one end 2-3 inches into the soil on green or yellowing grass (not dead grass). Cut the grass runners around the bottom edge of the can with a knife, if necessary. Slowly fill with water and count the number of chinch bugs that float to the top within 5 minutes. Keep the water level above the base of the grass plants during the 5 -minute period. If nothing emerges in the first area, examine 3 or 4 other areas.

\section{Damage}

Southern chinch bugs prefer open, sunny areas of St. Augustinegrass, possibly where temperatures are hotter or the thatch may be thicker. They live in the thatch and suck fluids from the crowns, stems and stolons with their needle-like mouthparts. Infested grass turns yellow, then a burnt-reddish color, and dies. Chinch bugs tend to feed in groups, so dead patches of grass appear and seem to get larger as the insects spread through the grass. Severe damage tends to occur from March through November in southern Florida and from April through October in northern Florida.

\section{Control}

\section{Resistant Varieties}

Several varieties of St. Augustinegrass are used in Florida lawns, but the most common is Floratam. Floratam was once very resistant to chinch bug damage, but most chinch bugs can now develop on and damage this variety. Two new varieties, NUF-76 and NUF-216, with chinch bug resistant qualities are currently under production and testing.

\section{Beneficial Insects}

Common predators of the southern chinch bug are big-eyed bugs (Geocoris spp.), earwigs (Labidura spp.), and anthocorids. A small wasp, Eumicrosoma benefica, parasitizes chinch bug eggs. Big-eyed bugs and anthocorids are similar to chinch bugs in size and shape and are often mistaken for them (Figure 11).
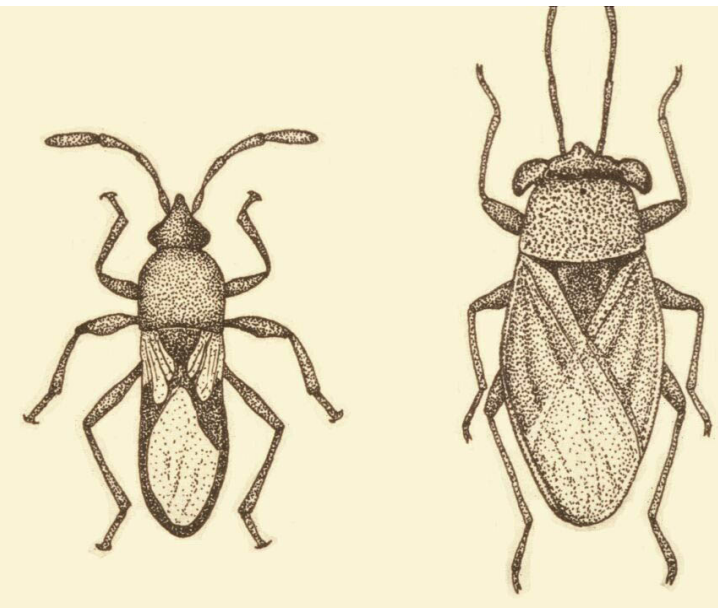

Figure 11. Adult southern chinch bug (left) and big-eyed bug (right).

\section{Control with Pesticides}

If 20 to 25 chinch bugs per square foot are detected, an insecticide application may be needed. Buy an insecticide that is specifically labeled for chinch bug control. Read and understand all directions on the container label regarding dosage rates, application information and precautions. Spot treat with a 5-foot buffer area when infestations are first noticed and damage is minimal, but treat the entire area if damage is widespread. Irrigate afterwards with $1 / 8$ inch of water to move the insecticide into the thatch. Inspect two to three times for the following 4 to 6 weeks to ensure that the 
infestation has been controlled. Because of pesticide resistance problems, avoid using the same product and chemiocal class (e.g., pyrethroid) successively.

\section{Spittlebugs}

\section{Description}

Two-lined spittlebug nymphs may be yellow, orange, or white, and are covered by a frothy mass of spittle. Adults (Figure 12) are about 1/4 to 1/2 inch long, black with two reddish-orange lines across the wings. Their eyes are dark red.

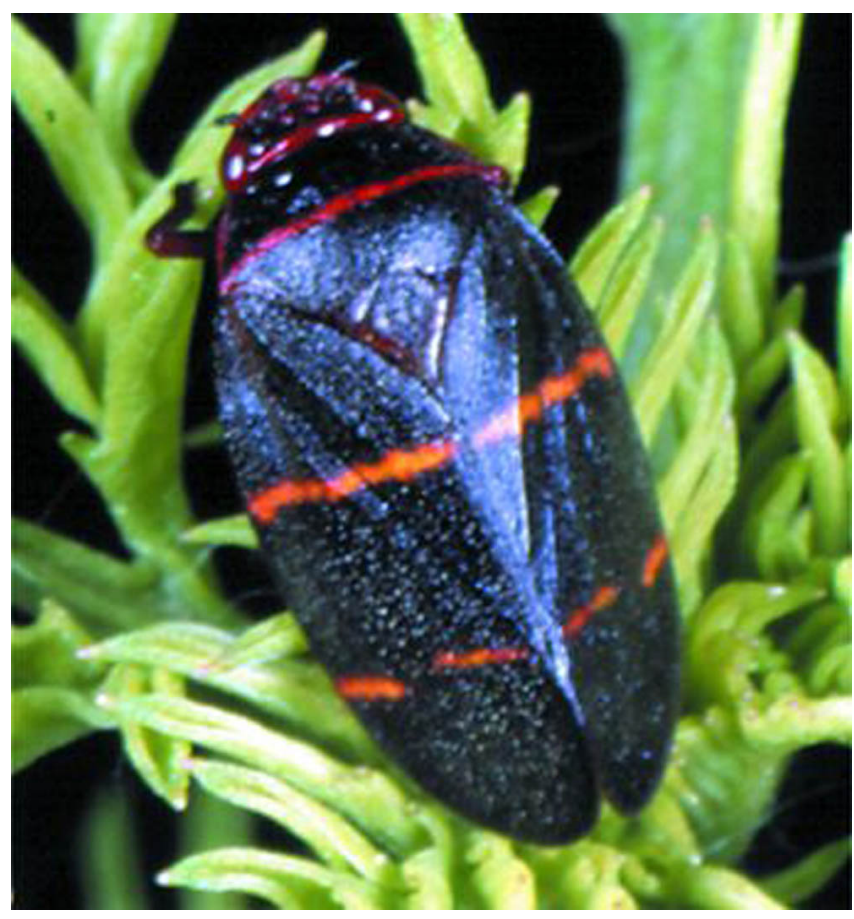

Figure 12. Two-lined spittlebug adult. Credits: L. J. Buss, University of Florida

\section{Life Cycle}

Spittlebugs occur throughout much of the state, but are more numerous in northern and northwestern Florida. Although they prefer centipedegrass, they will attack all turfgrass species, many crops and weeds, and ornamental plants, especially hollies. Eggs are laid at the base of the grass in the thatch, in hollow grass stems, or behind the leaf sheaths. One generation may last 2 to $21 / 2$ months, and there are two generations per year. Eggs laid by the second generation overwinter and hatch the following spring, from late March to late April. The first generation adults are abundant in June. The adult population peaks again in early August to early September.

\section{Monitoring}

Most spittle masses are not obvious because they are located near the soil surface or in the thatch, but they may be more visible in the morning. Adults are most active during the early morning hours, but hide near the soil surface during the heat of the day. They often jump from the leaf surfaces if the turf is disturbed.

\section{Damage}

Nymphs and adults suck plant juices through their piercing-sucking mouthparts. Damage is primarily caused by adults, which inject a phytotoxic substance into the plants while feeding. Infested turf wilts, and the tips turn yellow, eventually brown, and then curl.

\section{Control}

Spittlebugs are rarely a problem on well-managed turf. They need high humidity for optimum development, and excess thatch provides good habitat. Follow approved practices regarding mowing, fertilization and irrigation to reduce thatch buildup, and dethatch if necessary. If greater control is needed, purchase an insecticide specifically labeled for spittlebugs. Mow, dispose of clippings, and irrigate before an insecticide is applied so the insecticide effectively reaches the thatch layer.

\section{Tropical Sod Webworm}

\section{Description}

One of the most damaging caterpillars is the tropical sod webworm (Figure 13). Larvae are gray-green, and have brown spots on each segment. Mature larvae reach about 3/4 to 1 inch in length. Sod webworm adults are small, tan to gray moths with a wingspan of 3/4 to 1 inch.

\section{Life Cycle}

Eggs are deposited on the grass blades and hatch after about 1 week. Larvae feed on the grass blades and cause noticeable injury within 2 weeks. There may be rather extensive damage within the next 1 to $11 / 2$ weeks until pupation. Adults appear about 1 week later. Moths fly low to the grass when disturbed, and 


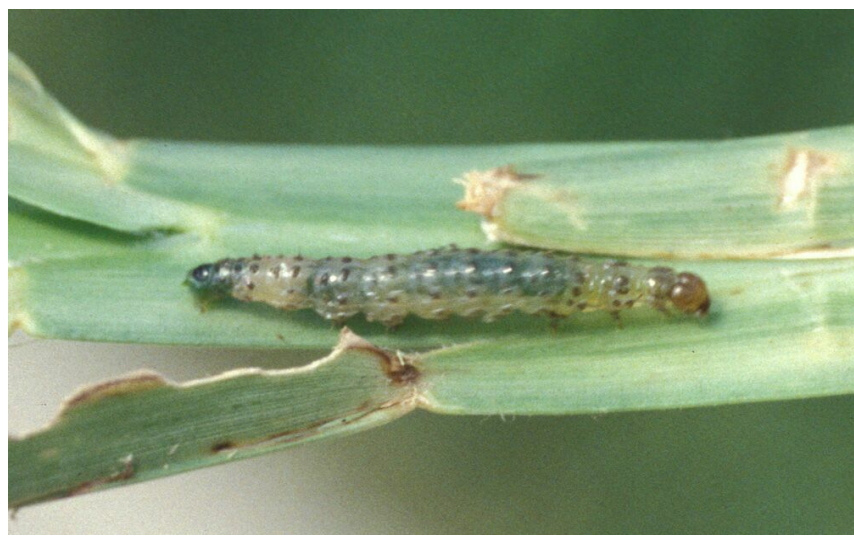

Figure 13. Tropical sod webworm.

hide in shrubs and other sheltered areas during the day. Three generations occur in north Florida and four generations occur in south Florida. Most activity occurs from April through November, but may occur year-round in southern Florida.

\section{Monitoring}

Part the grass in suspect areas and closely examine the soil surface. Look for chewed leaves, silken webs, green frass (excrement), and larvae. A flashlight used at night will reveal the caterpillars feeding in the grass foliage. Soap flushes (1-2 TBSP liquid dishwashing soap mixed in 1 gallon of water) also help by drenching larvae and other potential pests out of the ground. Pour the mixture on 1 square yard of damaged grass, and see what emerges within 5 minutes. If nothing emerges in the first area, examine at least 3 or 4 other places.

\section{Damage}

Tropical sod webworm damage becomes visible in June in southern Florida, July in central Florida, and August in northern Florida. The webworms feed primarily at night and remain in a curled position on or near the soil surface during the day. This habit makes them difficult to find. Newly hatched caterpillars cause little visible damage to grass, although they can skeletonize grass blades. Older caterpillars chew notches along the sides of the blades, and serious damage seems to occur almost overnight. The foliage may be almost completely stripped off in patches, and these close-cropped areas soon become yellowish to brownish. Adults do not cause damage.

\section{White Grubs}

\section{Description}

Several species of white grubs damage grass, including May or June beetles (Phyllophaga spp.) and masked chafers (Cyclocephala spp.). White grubs (Figure 14) are the creamy-white, C-shaped larvae of scarab beetles. They have brownish heads and six legs (unlike legless billbug larvae). Mature grubs vary in length from $1 / 4$ to 2 inches, depending on the species. The grubs also have a pattern of hairs (raster) on the tip of their abdomen, which is important in identification.

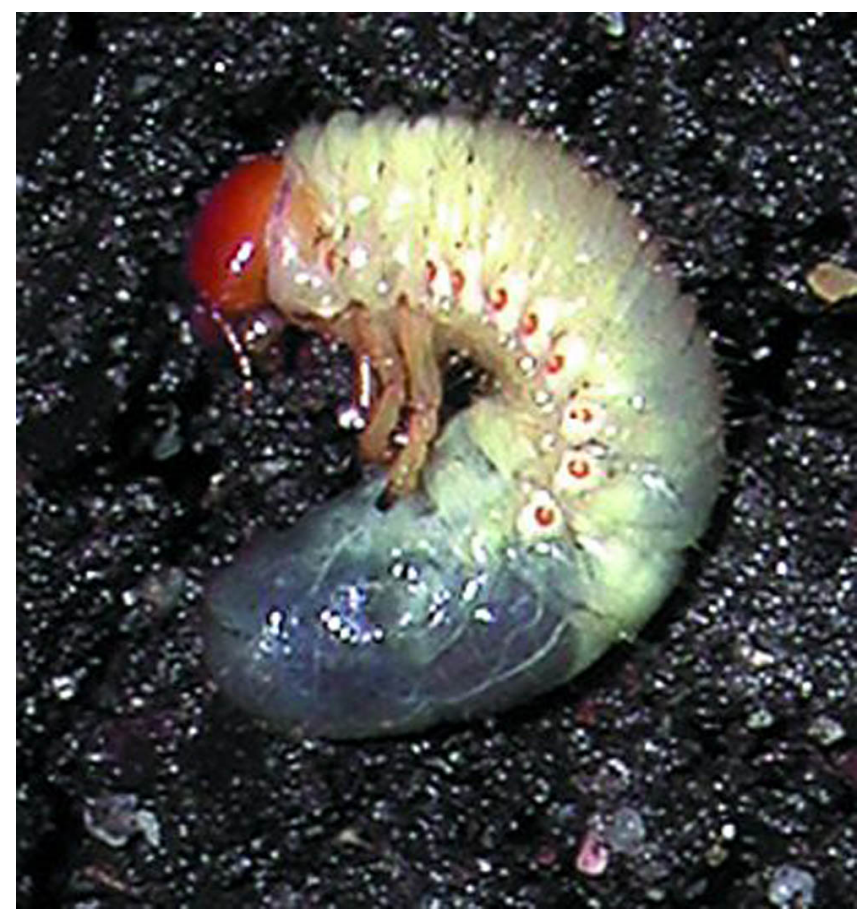

Figure 14. Masked chafer. Credits: J. L. Castner, University of Florida

\section{Life Cycle}

In Florida, masked chafers have about 2 generations per year. Adults are tan, about 5/8 inches long, and slightly smaller than May or June beetle adults. Adults are often present from April to June and September to October. Adults lay their eggs in the top inch or two of soil, often in small clusters. Small grubs hatch from the eggs and begin feeding on grass roots. They pupate in earthen cells and emerge as adults to begin a new cycle. 
Most May or June beetles develop in one year in Florida (except the Cuban May beetle, which develops in 6 months). Adults are active in the spring, from May to July. Adult females lay eggs in the soil, which hatch in a few days. The grubs feed on grass roots and organic matter. They pupate in earthen chambers in the soil.

\section{Monitoring}

If grubs are suspected, cut 2-3 inches deep in a 1 foot square area near damaged grass. Lay the grass back, check the quality of the roots, and look for grubs in the soil and thatch. Frass or tunneling may be visible, and grass roots will look pruned. Check several places in the turf. If grubs are commonly a problem in an area, examine all turf in July and August. Don't wait for brown patches to appear before inspecting the soil. It is normal to find a couple of small white grubs per square foot in turfgrass. The mere presence of a grub is not necessarily a problem, because healthy turf can easily outgrow minor root loss, but certain grubs (e.g., Tomarus subtropicus) can be damaging in low numbers. Also look for adult scarab beetles flying at night around windows or porch lights in the spring and early summer to determine when adults are active and laying eggs.

When grubs are found, examine their raster (hair) patterns, located on the bottom of the last abdominal segment, with a 10 or 15 -power hand lens (Figure 15). May or June beetle grubs have two very distinct rows of short hair, like a zipper, whereas chafer larvae have no distinct raster pattern.

\section{Damage}

White grubs occur throughout Florida, but tend to cause more damage along the Gulf and Atlantic Coasts. When white grubs feed on grass roots, the grass gradually yellows, wilts, thins, and dies. Scattered, irregular, brown patches of grass appear, which increase in size over time. The root injury reduces the turf's ability to take up water and nutrients and withstand the stress of hot, dry weather. Heavily infested grass will pull out easily. Grubs usually feed for several months before any turf damage becomes visible, and areas tend to be reinvaded year-after-year. Feeding by mature grubs can be severe. Adult beetles usually do not feed on

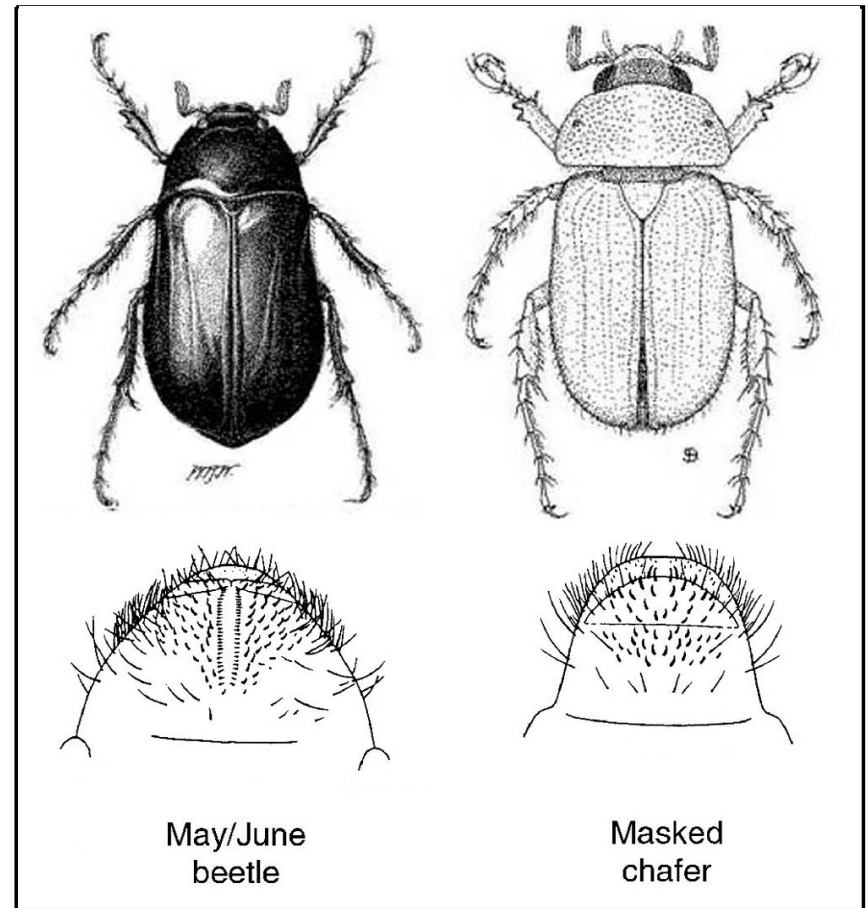

Figure 15. Adults and raster patterns of some white grubs found in Florida. Drawings do not indicate true size. Credits: Adapted from Ohio State University Cooperative Extension Service

grass, but may feed on flowers and foliage of ornamental plants and trees.

\section{Control}

Minimize conditions that attract beetles and favor grub development, such as leaving outdoor lights on during adult flights, and using organic fertilizers (important for Green June beetles).

Curative treatments are usually applied in late summer, after the eggs have hatched and 5 to 10 grubs are found per square foot. Because most insecticides used against grubs on turf have relatively short residuals (less than 2 weeks), a curative application needs to be timed correctly. The best time is when grubs are small and their feeding damage is relatively light. As they grow, they become progressively harder to control, and root damage may be severe. Monitor infestations to be sure of accurate timing, and irrigate with about $1 / 2$ inch of water after the application to keep the grubs near the soil surface and to wash in the pesticide.

White grubs tend to occur in localized populations, so an application "just in case" grubs are present is not advised. But, in those spots where 
grubs reoccur, preventive applications may help.

Preventive treatments increase flexibility in application timing, are easier to schedule and implement than curative treatments, and require less sampling and monitoring of grub populations. Such insecticides have a longer residual in the soil and give good control of newly hatched white grubs when applied weeks before grub hatch. But, the optimum timing is during the month or so before egg hatch until the time when very young grubs are present.

\section{Notes on Control}

Apply insecticides properly. Read and understand all directions on the container label regarding dosage rates, application information, and precautions. When a spray is applied for controlling insects, it is important to apply the insecticide in a large amount of water. The jar attachment to a garden hose is the suggested application device for lawns. The type that requires 15 to 20 gallons of water passing through the hose to empty the quart size jars is recommended. Put the amount of insecticide in the jar as directed on the label for 1000 square feet. Fill the jar the rest of the way with water. Spray the contents over 1000 square feet. To insure even coverage, spray back and forth across the measured area; then turn at right angles and spray back and forth across the same area.

When spraying for control of soil insects (mole crickets, white grubs and billbugs), the turf should be moist at the time of application. Immediately after spraying the insecticide, irrigate with about $1 / 2$ inch water to move the insecticide into the soil where the insects are feeding (as directed by the product label). Control of surface feeders (chinch bugs, lawn caterpillars, bermudagrass mites, grass scales and spittlebugs), do not irrigate after application, unless stated on the label.

Granular formulations for the recommended insecticides may be substituted for sprays in controlling chinch bugs, webworms, mole crickets, white grubs, or billbugs. If applied for soil insects (mole crickets, white grubs or billbugs), irrigate with water immediately after application.

To help prevent unnecessary environmental contamination and reduction of beneficial insects, spot treatments can be applied when infestations are first noticed and the damaged area is small. Treat the off-color area and about a 5 to 10-foot buffer area surrounding it. If damage is widespread over the yard or if many infested areas are detected, the entire yard should be treated. Inspect the area at biweekly intervals to determine if the infestation is under control.

\section{Precautions}

Insecticides are poisons and should be handled as such. Read the manufacturer's label carefully before opening the container and observe all instructions and precautions. Wear rubber gloves when handling and applying insecticides. Do not spill sprays on skin or clothing. Do not breathe mists or fumes. Wash exposed parts of the body with soap and water immediately after using insecticides.

Store pesticides locked up in original labeled containers, and out of reach of children. Rinse empty containers and put rinse water in spray tank. To dispose of the empty container (1 gallon or smaller), wrap in newspaper, crush or puncture to prevent reuse, and put in garbage can for disposal in an approved sanitary landfill. 